\title{
Prehypertensive State, Mild Hypertension, Metabolic Syndrome and Cardiovascular Risk Factors among Young Adults in Rural Malaysia
}

\author{
Abdullah Aszrin ${ }^{a}$, Shah M Azarisman ${ }^{b^{*}}$, Rahman A Jamaluddin ${ }^{c^{*}}$, Razak A Tariq ${ }^{b^{*}}$, Noor M Noriah ${ }^{d^{*}}$ \\ ${ }^{a}$ Department of Basic Medical Sciences, Faculty of Medicine \\ ${ }^{b}$ Department of Internal Medicine, Faculty of Medicine \\ 'Department of Community Medicine, Faculty of Medicine \\ ${ }^{d}$ Department of Basic Medical Sciences, Faculty of Pharmacy \\ International Islamic University Malaysia, Kuantan, Malaysia
}

\begin{abstract}
Introduction: Prehypertension precedes overt hypertension and has been acknowledged by many guidelines. Hypertension is an important risk factor for cardiovascular disease in Malaysia. Hypertension prevalence is at $42.6 \%$ and population-based control is poor at $26.8 \%$. The objective of the study is to ascertain the cardiovascular risk profile of prehypertensive and mildly hypertensive young adults against age-matched controls in rural Malaysia. Methods: 484 (four hundred and eighty four) subjects attending primary care clinic were screened. 91 (Ninety one) young adults with pre/mild hypertension and normotensive, agematched controls were enrolled. The blood pressure and biochemical profiles for both groups were assessed and compared. Results: Fifty-four subjects and 37 controls were enrolled. Amongst subjects, $46.3 \%$ had prehypertension and $53.7 \%$ had mild hypertension. Mean values compared to age-matched controls for MAP were $102.68 \pm 7.48$ vs $83.25 \pm 6.08 \mathrm{mmHg}(p<0.001)$, LDL $3.75 \pm 0.95$ vs $3.32 \pm 0.93 \mathrm{mmol} / \mathrm{L}(\mathrm{p}=0.03)$, FBG $4.65 \pm 0.54$ vs $4.33 \pm 0.42 \mathrm{mmol} / \mathrm{L}(\mathrm{p}=0.03)$, BMI $28.81 \pm 5.16$ vs $24.12 \pm 4.91(p<0.001)$. The mean $B P$ was significantly associated with BMI, FBG, triglycerides, $\mathrm{HDL}$ and the TC/HDL ratio. Conclusions: Greater BMI, FBG, HDL, triglyceride levels and TC/HDL ratio characterised the young adults with pre/mild hypertension. The data suggests that hypertension in young adults is secondary to metabolic syndrome.
\end{abstract}

KEYWORDS: Prehypertension, hypertension, metabolic syndrome, young adults, cardiovascular risk.

\section{INTRODUCTION}

Hypertension has a significant impact on the world's population morbidity and mortality. ${ }^{1-3}$ It was estimated in 2000 that $26.4 \%$ of the world's adult population had hypertension, $34.3 \%$ in developed countries and $65.7 \%$ in economically developing countries. ${ }^{4}$ Malaysia's third National Health and Morbidity Survey (NHMS III) in 2006 reported that hypertension afflicted $43 \%$ of adults over the age of 30 , compared to $33 \%$ in the prior decade as reported in the second NHMS in $1996 . .^{5}$ The increasing prevalence of hypertension proved that hypertension is a serious health problem in Malaysia.

Corresponding author:

Prof. Dr. Shah M Azarisman

MBBS, MMED, Fellow ISHNE.

Consultant Cardiologist,

Department of Internal Medicine,

Faculty of Medicine

International Islamic University Malaysia

Tel: 09-5704727

Email: risman1973@hotmail.com
Hypertension results from a complex relationship between genetic, environmental, and behavioural factors that have its origins in the young. ${ }^{6}$ Population changes in health-related behaviours, such as childhood obesity have resulted in significant rises in hypertension prevalence in the young. ${ }^{7}$ Moreover, at least half of hypertensive patients present with a cluster of metabolic abnormalities known as insulin resistance or metabolic syndrome. ${ }^{8}$

Prehypertension is defined as a subgroup within the stages of hypertension with a blood pressure level of 120-139 mm systolic and $80-89 \mathrm{mmHg}$ diastolic. ${ }^{9}$ Prehypertension per se is not a disease, but a warning of risk as cardiovascular disease and stroke increased in a log-linear proportion with both SBP and DBP values over $115 / 75 \mathrm{mmHg}{ }^{1}$

Metabolic syndrome is defined as a collection of features such as visceral obesity, impaired glucose tolerance, dyslipidemia, hypergtriglyceridemia, and elevated blood pressure. ${ }^{10,11}$ It is highly prevalent and is a risk factor in the incidence of cardiovascular heart disease. ${ }^{12}$ Furthermore, studies have found that the prevalence of metabolic syndrome increases with 
age. ${ }^{13}$ However, studies on the earliest manifestation of metabolic syndrome in young adult hypertensives are still limited. The objective of this study is to ascertain the relationship between young adults with prehypertension and hypertension, and the cluster of features known as metabolic syndrome compared to age-matched controls.

\section{METHODS}

\section{Study Sample}

The study was conducted in a major primary health care referral centre for non-communicable disease in Kuantan, the capital of Pahang. Pahang has an essentially agrarian economy, predominantly rural populace which is primarily catered by the public health care sector. The study protocol was approved by the Medical Research and Ethics Committee of the institution (NMRR-08-1276-2470), written informed consents were obtained from all subjects and the study was conducted in concordance with the Code of Ethics of the World Medical Association (Declaration of Helsinki, 1964 and Declaration of Tokyo, 1975, as revised in 1983).

Consecutive patients (484) between the ages of 20 and 45 years were screened. Sixty young adults with hypertension attending the aforementioned clinic, who satisfied the inclusion criteria, were enrolled into a cross-sectional study. Forty control participants were sourced from the same clinic, amongst family members accompanying the patients during their visits and several public health screening activities around Kuantan.

All patients satisfying the pre-hypertension (high normal with systolic blood pressure 120-139 mmHg and/or diastolic blood pressure of $80-89 \mathrm{mmHg}$ on at least two separate occasions) or newly diagnosed patients with mild hypertension (systolic blood pressure of $140-159 \mathrm{mmHg}$ and/or diastolic blood pressure of $90-99 \mathrm{mmHg}$ on 2 different occasions or stage 1 hypertension) and not on any antihypertensives were recruited into the study.

Patients who had any of the following criteria, 1) presence of end organ damage, for instance left ventricular hypertrophy OR proteinuria, 2) positive history related to hypertensive complications such as congestive heart failure OR cerebrovascular accident, 3) presence of secondary causes of hypertension from history, physical examination or investigation, 4) diagnosed with other chronic illnesses such as diabetes mellitus, renal disease, hyperlipidemia and are on other chronic medications and 5) established hypertensive patients on regular treatment but resting blood pressure more than $140 / 90 \mathrm{mmHg}$, were excluded from the study.

\section{Study Protocol}

During the first screening visit, the participants were requested to fast overnight (minimum of 8 hours) before the next appointment for fasting blood samples. The first blood pressure (BP) measurement was then performed. This was followed by the second, viz recruitment visit 1 week later. Appointments for the studies were prearranged to be scheduled in the morning $(8-10$ am) and in a controlled room temperature $\left(23-25^{\circ}\right.$ C).

Questionnaires were administered to attain participants' socio-demographic background and their Framingham's Cardiovascular Risk Assessment. BP was then measured in supine position and blood samples were drawn for biochemical profile (lipid profile, blood glucose, renal profile).

\section{Statistical Analysis}

Data for continuous, closely symmetrical variables were analysed using standard descriptive methods to estimate means and standard deviation. The comparison between means was determined using the independent sample $t$-test. Discrete data and proportions are compared using $\mathrm{x}^{2}$ test, with the level of statistical significance set at $p<0.05$. All statistical analyses were performed with SPSS Version 18 (SPSS Inc. Released 2009. PASW Statistics for Windows, Version 18.0. Chicago: SPSS Inc.).

\section{RESULTS}

\section{Characteristics of Study Participants}

Sixty patients between the ages of 20 and 45 years, with systolic and diastolic blood pressure ranges of between $120-159 \mathrm{mmHg}$ and $80-99 \mathrm{mmHg}$ respectively and 40 age-gender matched controls with optimal BP $(<120 / 80 \mathrm{mmHg})$, were recruited into the study. However, only 91 participants (54 in the patient group and 37 matched controls) who fulfilled the entry criteria were finally included as 9 subjects defaulted the second visit appointment for blood collection. Eighty percent of study subjects had tonometry or central aortic systolic pressure (CASP) measurements repeated twice or more. 
Table 1 Characteristics of Human Study Subjects

\begin{tabular}{|c|c|c|c|}
\hline & $\begin{array}{l}\text { Patients } \\
(\mathrm{N}=54)\end{array}$ & $\begin{array}{l}\text { Controls } \\
(\mathrm{N}=37)\end{array}$ & P value* \\
\hline Age (years) & $33.87 \pm 6.56$ & $\begin{array}{l}29.68 \pm \\
4.71\end{array}$ & 0.001 \\
\hline Males & $\begin{array}{l}30 \\
(55.60 \%)\end{array}$ & $\begin{array}{l}19 \\
51.40 \%)\end{array}$ & 0.69 \\
\hline Smokers & $14.8 \%$ & $13.5 \%$ & 0.86 \\
\hline $\begin{array}{l}\text { Family } \\
\text { History of } \\
\text { Hypertension }\end{array}$ & $83.3 \%$ & $58.8 \%$ & 0.01 \\
\hline Weight (kg) & $75.97 \pm 14.45$ & $\begin{array}{l}62.43 \pm \\
14.41\end{array}$ & $<0.001$ \\
\hline $\begin{array}{l}\text { Height } \\
\text { (meter) }\end{array}$ & $1.63 \pm 0.09$ & $\begin{array}{l}1.60 \pm \\
0.09\end{array}$ & 0.20 \\
\hline BMI $\left(\mathrm{kg} / \mathrm{m}^{2}\right)$ & $28.81 \pm 5.16$ & $\begin{array}{l}24.12 \pm \\
4.91\end{array}$ & $<0.001$ \\
\hline $\begin{array}{l}\text { Systolic BP } \\
(\mathrm{mmHg})\end{array}$ & $133.53 \pm 10.57$ & $\begin{array}{l}109.10 \pm \\
6.93\end{array}$ & $<0.001$ \\
\hline $\begin{array}{l}\text { Diastolic BP } \\
(\mathrm{mmHg})\end{array}$ & $87.54 \pm 7.73$ & $\begin{array}{l}70.32 \pm \\
6.30\end{array}$ & $<0.001$ \\
\hline $\begin{array}{l}\text { Mean Arterial } \\
\text { Pressure } \\
(\mathrm{mmHg})\end{array}$ & $102.68 \pm 7.48$ & $\begin{array}{l}83.25 \pm \\
6.08\end{array}$ & $<0.001$ \\
\hline $\begin{array}{l}\text { Heart rate } \\
\text { (beats/ } \\
\text { minute) }\end{array}$ & $79.31 \pm 9.75$ & $\begin{array}{l}74.00 \pm \\
9.47\end{array}$ & 0.01 \\
\hline CASP $(\mathrm{mmHg})$ & $123.93 \pm 10.49$ & $\begin{array}{l}101.30 \pm \\
6.26\end{array}$ & $<0.001$ \\
\hline CV risk score & $4.56 \pm 5.62$ & $\begin{array}{l}-0.43 \pm \\
4.25\end{array}$ & $<0.001$ \\
\hline
\end{tabular}

Data are expressed in mean \pm SD and percentage.

* $p$ value for comparison between the three groups.

Overall, subjects from both patient and control groups were equally proportioned in terms of gender. Although there was a statistically significant difference between the mean ages of the two groups, all patient and control group subjects lay within the same predetermined age group (20-45 years old) (Table 1). Among the subjects in the patient group, $46.3 \%$ had prehypertension and $53.7 \%$ had stage 1 hypertension. The patient group had significantly higher percentage of self-reported family history of hypertension in their first degree relatives $(p=0.01)$. They also had a significantly greater $B M I$ $(p<0.001)$, heart rate $(p=0.01)$, CASP $(p<0.001)$ and $C V$ risk score $(p<0.001)$. In addition, more subjects in the patient group had moderate-to-high 10-year risk of developing coronary artery diseases compared to the control group; $13.0 \%$ and $0 \%$ respectively $(p=0.01)$.

Further division of the subjects into three BP category groups, revealed a similar trend as observed in Table 2. A higher percentage of subjects with a self-reported family history of hypertension in their first degree relatives was seen in the prehypertension and stage 1 hypertension groups compared to the subjects with optimal BP $(p=0.03)$. Significant differences across the three BP groups were found for $B M I(p<0.001)$, heart rate $(p=0.01)$, CASP $(p<0.001)$ and CV risk score $(p<0.001)$. From the subjects studied, $20.7 \%$ of subjects in the stage 1 hypertension had moderate-to-high 10-year risk of developing coronary artery diseases while the prehypertension and optimal BP groups had $4 \%$ and $0 \%$, respectively $(p=0.01)$.

Table 2 Characteristics of Human Study Subjects According to Blood Pressure Classification

\begin{tabular}{|c|c|c|c|c|}
\hline & $\begin{array}{l}\text { Optimal } \\
\mathrm{BP} \\
(\mathrm{N}=37)\end{array}$ & $\begin{array}{l}\text { Prehyper- } \\
\text { tension } \\
(\mathrm{N}=25) \\
\end{array}$ & $\begin{array}{l}\text { Stage } 1 \\
(N=29)\end{array}$ & $\begin{array}{c}\mathrm{p} \\
\text { value* }\end{array}$ \\
\hline Age (years) & $\begin{array}{l}29.68 \pm \\
4.71\end{array}$ & $\begin{array}{l}32.28 \pm \\
5.98\end{array}$ & $\begin{array}{l}35.24 \pm \\
6.84\end{array}$ & 0.001 \\
\hline Males & $51.4 \%$ & $56.0 \%$ & $55.2 \%$ & 0.92 \\
\hline Smokers & $13.5 \%$ & $4.0 \%$ & $24.1 \%$ & 0.11 \\
\hline $\begin{array}{l}\text { Family } \\
\text { History of } \\
\text { Hyperten- } \\
\text { sion }\end{array}$ & $58.8 \%$ & $80.0 \%$ & $86.2 \%$ & 0.03 \\
\hline $\begin{array}{l}\text { Weight } \\
(\mathrm{kg})\end{array}$ & $\begin{array}{l}62.43 \pm \\
14.41\end{array}$ & $\begin{array}{l}75.68 \pm \\
16.39\end{array}$ & $\begin{array}{l}76.22 \pm \\
12.89\end{array}$ & $\begin{array}{l}< \\
0.001\end{array}$ \\
\hline $\begin{array}{l}\text { Height } \\
\text { (meter) }\end{array}$ & $\begin{array}{l}1.60 \pm \\
0.09\end{array}$ & $\begin{array}{l}1.62 \pm \\
0.09\end{array}$ & $\begin{array}{l}1.63 \pm \\
0.09\end{array}$ & 0.43 \\
\hline $\begin{array}{l}\mathrm{BMI}(\mathrm{kg} / \\
\left.\mathrm{m}^{2}\right)\end{array}$ & $\begin{array}{l}24.12 \pm \\
4.91\end{array}$ & $\begin{array}{l}29.00 \pm \\
6.18\end{array}$ & $\begin{array}{l}28.65 \pm \\
4.20\end{array}$ & $\begin{array}{l}< \\
0.001\end{array}$ \\
\hline $\begin{array}{l}\text { Heart rate } \\
\text { (beats/ } \\
\text { minute) }\end{array}$ & $\begin{array}{l}74.00 \pm \\
9.47\end{array}$ & $\begin{array}{l}77.16 \pm \\
10.80\end{array}$ & $\begin{array}{l}81.17 \pm \\
8.51\end{array}$ & 0.01 \\
\hline $\begin{array}{l}\text { CASP } \\
(\mathrm{mmHg})\end{array}$ & $\begin{array}{l}101.30 \pm \\
6.26\end{array}$ & $\begin{array}{l}116.80 \pm \\
7.39\end{array}$ & $\begin{array}{l}130.07 \pm \\
8.78\end{array}$ & $\begin{array}{l}< \\
0.001\end{array}$ \\
\hline $\begin{array}{l}\text { CV risk } \\
\text { score }\end{array}$ & $\begin{array}{l}-0.43 \pm \\
4.25\end{array}$ & $\begin{array}{l}1.76 \pm \\
4.08\end{array}$ & $\begin{array}{l}7.00 \pm \\
5.70\end{array}$ & $\begin{array}{l}< \\
0.001\end{array}$ \\
\hline
\end{tabular}

Data are expressed in mean + SD.

${ }^{*} \mathrm{P}$ value for comparison among the three blood pressure groups.

\section{Biochemistry Values/Profile}

Total cholesterol, uric acid and creatinine values were similar between the patient and control groups or across the three BP category groups (Table 3a). Comparison of fasting blood glucose (FBG), lowdensity lipoprotein cholesterol (LDL), triglycerides (TG) and high-density lipoprotein cholesterol (HDL) and total cholesterol and $\mathrm{HDL}$ ratio (TC/HDL ratio) of patient and control groups subjects showed that there were significant differences between the two groups. The differences were also observed following division of the subjects into the three BP subtypes (Table $3 b$ ). Prehypertension group and stage 1 hypertensive group 
subjects both had higher FBG, LDL, HDL and TG and $\mathrm{TC} / \mathrm{HDL}$ ratio compared to the optimal BP group. Nevertheless, LDL was not statistically different when compared between the three groups.

Table 3a Biochemical Profile of Subjects

\begin{tabular}{|c|c|c|c|}
\hline & $\begin{array}{l}\text { Patients } \\
(\mathrm{N}=54)\end{array}$ & $\begin{array}{l}\text { Controls } \\
(\mathrm{N}=37)\end{array}$ & $p$ value* \\
\hline FBG $(\mathrm{mmol} / \mathrm{L})$ & $4.65 \pm 0.54$ & $4.33 \pm 0.42$ & 0.03 \\
\hline $\mathrm{HDL}(\mathrm{mmol} / \mathrm{L})$ & $1.33 \pm 0.35$ & $1.73 \pm 0.46$ & $<0.001$ \\
\hline LDL (mmol/L) & $3.75 \pm 0.95$ & $3.32 \pm 0.93$ & 0.03 \\
\hline $\begin{array}{l}\text { Triglyceride } \\
\text { (mmol/L) }\end{array}$ & $1.68 \pm 0.88$ & $1.01 \pm 0.54$ & $<0.001$ \\
\hline $\begin{array}{l}\text { Tot Chol } \\
\text { (mmol/L) }\end{array}$ & $5.82 \pm 1.03$ & $5.51 \pm 1.03$ & 0.16 \\
\hline $\mathrm{TC} / \mathrm{HDL}$ ratio & $4.58 \pm 1.16$ & $3.34 \pm 0.98$ & $<0.001$ \\
\hline $\begin{array}{l}\text { Se Uric Acid } \\
(\mathrm{mmol} / \mathrm{L})\end{array}$ & $0.39 \pm 0.12$ & $0.40 \pm 0.45$ & 0.79 \\
\hline $\begin{array}{l}\text { Se Creatinine } \\
\text { (umol/L) }\end{array}$ & $\begin{array}{l}91.43 \pm \\
17.19\end{array}$ & $\begin{array}{l}90.00 \pm \\
16.67\end{array}$ & 0.70 \\
\hline
\end{tabular}

Data are in mean + SD.

* $\mathrm{P}$ value for comparison between the two groups.

Table 3b Biochemical Profile of Subjects According to Blood Pressure Classification

\begin{tabular}{|c|c|c|c|c|}
\hline & $\begin{array}{l}\text { Optimal } \\
\mathrm{BP} \\
(\mathrm{N}=37)\end{array}$ & $\begin{array}{l}\text { Prehyper- } \\
\text { tension } \\
(\mathrm{N}=25)\end{array}$ & $\begin{array}{l}\text { Stage1 } \\
(\mathrm{N}=29)\end{array}$ & $\begin{array}{l}\mathrm{p} \\
\text { value* }\end{array}$ \\
\hline $\begin{array}{l}\text { FBG } \\
(\mathrm{mmol} / \mathrm{L})\end{array}$ & $\begin{array}{c}4.33 \pm \\
0.42\end{array}$ & $\begin{array}{c}4.48 \pm \\
0.43\end{array}$ & $\begin{array}{c}4.80 \pm \\
0.58\end{array}$ & 0.001 \\
\hline $\begin{array}{l}\mathrm{HDL} \\
(\mathrm{mmol} / \mathrm{L})\end{array}$ & $\begin{array}{l}1.73 \pm \\
0.46\end{array}$ & $\begin{array}{c}1.49 \pm \\
0.37\end{array}$ & $\begin{array}{c}1.20 \pm \\
0.27\end{array}$ & $<0.001$ \\
\hline $\begin{array}{l}\mathrm{LDL} \\
(\mathrm{mmol} / \mathrm{L})\end{array}$ & $\begin{array}{c}3.32 \pm \\
0.93\end{array}$ & $\begin{array}{l}3.72 \pm \\
0.85\end{array}$ & $\begin{array}{c}3.78 \pm \\
1.05\end{array}$ & 0.10 \\
\hline $\begin{array}{l}\text { Triglycer- } \\
\text { ide } \\
(\mathrm{mmol} / \mathrm{L})\end{array}$ & $\begin{array}{c}1.01 \pm \\
0.54\end{array}$ & $\begin{array}{c}1.53 \pm \\
0.66\end{array}$ & $\begin{array}{c}1.82 \pm \\
1.01\end{array}$ & $<0.001$ \\
\hline $\begin{array}{l}\text { Total } \\
\text { Cholesterol } \\
(\mathrm{mmol} / \mathrm{L})\end{array}$ & $\begin{array}{c}5.51 \pm \\
1.03\end{array}$ & $\begin{array}{c}5.90 \pm \\
0.92\end{array}$ & $\begin{array}{c}5.76 \pm \\
1.12\end{array}$ & 0.33 \\
\hline $\begin{array}{l}\mathrm{TC} / \mathrm{HDL} \\
\text { ratio }\end{array}$ & $\begin{array}{c}3.34 \pm \\
0.98\end{array}$ & $\begin{array}{c}4.12 \pm \\
1.01\end{array}$ & $\begin{array}{c}4.97 \pm \\
1.16\end{array}$ & $<0.001$ \\
\hline $\begin{array}{l}\text { Se Uric } \\
\text { Acid } \\
(\mathrm{mmol} / \mathrm{L})\end{array}$ & $\begin{array}{c}0.40 \pm \\
0.45\end{array}$ & $\begin{array}{c}0.38 \pm \\
0.13\end{array}$ & $\begin{array}{c}0.40 \pm \\
0.12\end{array}$ & 0.94 \\
\hline $\begin{array}{l}\text { Se } \\
\text { Creatinine } \\
\text { (umol/L) }\end{array}$ & $\begin{array}{c}90.00 \pm \\
16.67\end{array}$ & $\begin{array}{c}91.64 \pm \\
20.09\end{array}$ & $\begin{array}{c}91.24 \pm \\
14.60\end{array}$ & 0.92 \\
\hline
\end{tabular}

Data are expressed in mean $\pm \mathrm{SD}$.

* $\mathrm{P}$ value for comparison among the three blood pressure groups.

\section{Correlations}

There was significant but weak to moderate correlation between CASP and all other variables such as SBP, DBP, MAP, BMI, FBG, TG, HDL and TC/ HDL ratio across all subjects, as seen in Table 4a. Additionally, the CV score of all subjects was also correlated with the aforementioned variables including the heart rate, fasting blood levels of total cholesterol and LDL cholesterol, as in Table $4 a$ and Figure 1. The mean BP (SBP, DBP, MAP) of subjects was significantly associated with heart rate, BMI, FBG, TG, HDL and the TC/HDL ratio (Table 4b).

\section{Regression Analysis}

Univariate linear regression analysis identified FBG, $\mathrm{HDL}, \mathrm{TG}$ and BMI to be independently associated with both systolic and diastolic blood pressures. However multivariate linear regression analysis found $F B G, H D L$ and $B M I$ to be independently associated with systolic blood pressure $\left(R^{2} 0.338, p=\right.$ $0.004,0.024,0.006$ respectively) and only BMI was independently associated with diastolic blood pressure $\left(R^{2} 0.283, p=0.007\right)$

Table 4a Association Between Other Variables in All Subjects $(\mathrm{N}=91)$

\begin{tabular}{|c|c|c|}
\hline & CV Score & CASP \\
\hline Mean SBP & $r=0.44(p<0.001)^{*}$ & $r=0.96(p<0.001)^{*}$ \\
\hline Mean DBP & $r=0.50(p<0.001)^{*}$ & $r=0.81(p<0.001)^{*}$ \\
\hline MAP & $r=0.49(p<0.001)^{*}$ & $r=0.91(p<0.001)^{*}$ \\
\hline CASP & $r=0.50(p<0.001)^{*}$ & \\
\hline CV score & & $r=0.50(p<0.001)^{*}$ \\
\hline BMI & $r=0.2(p=0.02)^{*}$ & $r=0.26(p=0.01)^{*}$ \\
\hline Heart rate & $r=0.22(p=0.04)^{*}$ & $r=0.17(p=0.11)$ \\
\hline Creatinine & $r=-0.10(p=0.36)$ & $r=0.11(p=0.31)$ \\
\hline FBG & $r=0.30(p=0.004)^{*}$ & $r=0.38(p<0.001)^{*}$ \\
\hline TChol & $r=0.42\left(p<0.001^{*}\right.$ & $r=0.99(p=0.002)^{*}$ \\
\hline HDL & $r=-0.2(p=0.01)^{*}$ & $r=-0.50(p<0.001)^{*}$ \\
\hline LDL & $r=0.4(p<0.001)^{*}$ & $r=0.1 \quad(p=0.36)$ \\
\hline TG & $r=0.41(p<0.001)^{*}$ & $r=0.37(p<0.001)^{*}$ \\
\hline $\mathrm{TC} / \mathrm{HDL}$ ratio & $r=0.56(p<0.001)^{*}$ & $r=0.46(p<0.001)^{*}$ \\
\hline
\end{tabular}

* Significant $p$ value for the correlation of variables 

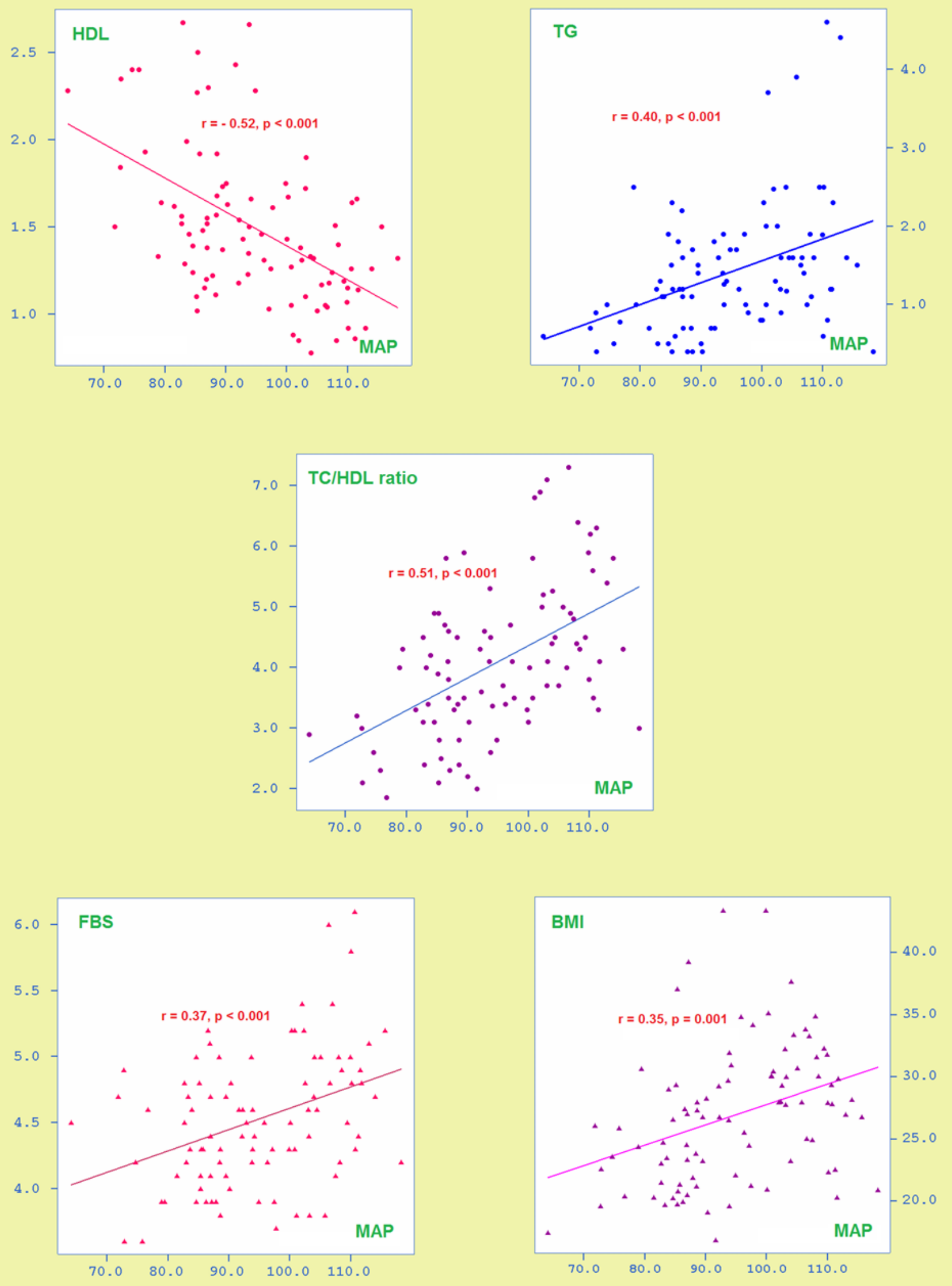

Figure 1 Association Between Mean Blood Pressure and Other Variables in All Subjects ( $\mathrm{N}=91)$ 
Table 4b Association Between Mean Blood Pressure and Other Variables in All Subjects $(\mathrm{N}=91)$

\begin{tabular}{|c|c|c|c|}
\hline & MAP & Mean SBP & Mean DBP \\
\hline $\begin{array}{l}\text { Heart } \\
\text { rate }\end{array}$ & $\begin{array}{c}r=0.30 \\
(p=0.004)^{*}\end{array}$ & $\begin{array}{l}r=0.21 \\
(p=0.04)^{*}\end{array}$ & $r=0.32(p=0.002)^{*}$ \\
\hline BMI & $\begin{array}{c}r=0.35(p= \\
0.001)^{*}\end{array}$ & $\begin{array}{l}r=0.31 \\
(p=0.003)^{*}\end{array}$ & $r=0.33(p=0.001)^{*}$ \\
\hline FBG & $\begin{array}{c}r=0.37 \\
(p<0.001)^{*}\end{array}$ & $\begin{array}{l}r=0.41 \\
(p<0.001)^{*}\end{array}$ & $r=0.32(p=0.002)^{*}$ \\
\hline TChol & $\begin{array}{l}r=\quad 0.05 \\
(p=0.61)\end{array}$ & $\begin{array}{l}r=-0.02 \\
(p=0.88)\end{array}$ & $r=0.10(p=0.34)$ \\
\hline HDL & $\begin{array}{c}r=-0.52 \\
(p<0.001)^{*}\end{array}$ & $\begin{array}{l}r=-0.55 \\
(p<0.001)^{*}\end{array}$ & $r=-0.45(p<0.001)^{*}$ \\
\hline LDL & $\begin{array}{l}r=\quad 0.15 \\
(p=0.15)\end{array}$ & $\begin{array}{l}r=0.10 \\
(p=0.34)\end{array}$ & $r=0.18(p=0.10)$ \\
\hline TG & $\begin{array}{c}r=0.40 \\
(p<0.001)^{*}\end{array}$ & $\begin{array}{l}r=0.37 \\
(p<0.001)^{*}\end{array}$ & $r=0.39(p<0.001)^{*}$ \\
\hline $\begin{array}{c}\mathrm{TCl} \\
\mathrm{HDL} \\
\text { ratio }\end{array}$ & $\begin{array}{c}r=0.51 \\
(p<0.001)^{*}\end{array}$ & $\begin{array}{l}r=0.48 \\
(p<0.001)^{*}\end{array}$ & $r=0.47(p<0.001)^{*}$ \\
\hline
\end{tabular}

* Significant $p$ value for the correlation of variables

\section{DISCUSSION}

\section{Biochemical Values/Profile and its Role in Assessment of Young Adults}

In this study, greater BMI, and higher FBG, HDL, TG levels and TC /HDL ratio significantly characterised the prehypertension and mild hypertension compared to controls. Our study also revealed that $12.4 \%$ of the study population had prehypertension and mild hypertension which frequently co-exists with increased BMI. The mean SBP, DBP and MAP of the young adults were also positively correlated with the above cardiovascular risk factors. This suggests that essential hypertension in young adults, is part of a metabolic syndrome. Perhaps prehypertension BP also indicates a "pre-metabolic syndrome state". These metabolic abnormalities, hypertension and other CV risk factor components are likely to be inseparable as found by other studies. ${ }^{11}$

Metabolic syndrome has been well described. It is characterised by metabolic abnormalities and development of CV risk factors such as hypertension, impaired insulin sensitivity, dyslipidaemia, hyperglycaemia, a systemic inflammatory state and abdominal obesity. It is related to increased risk of CV morbidity and mortality. ${ }^{14,15}$

\section{The 10-year Cardiovascular Risk Assessment of Young Hypertensives/ hypertensive patients}

Risk factor calculation assists in determining the global effect of hypertension and individually,) aids in the appropriate level of intervention required. In this study, the 10-year CV risk assessment of young pre-hypertensive and mild essential hypertensives/ hypertensive patients indicates that CV risk scores for these groups were significantly higher compared to the optimally normotensive group.

Current consensus dictates a non-pharmacological approach to the management of these patients. ${ }^{16}$ Presently pharmacological therapy is only advocated if an individual's BP is $\geq 160 / 100 \mathrm{mmHg}$ or when the SBP is between 140 and $159 \mathrm{mmHg}$ and/or sustained DBP between 90 and $99 \mathrm{mmHg}$ inclusive of the presence of $\mathrm{CV}$ disease or any other target organ damage. $^{16}$

Our study concurs with other studies and suggests the need for earlier screening and intervention for young hypertensive patients. However, this is beyond the scope of the present study. Studies on the cost-benefit and/or effectiveness of treating this group along with the appropriate antihypertensive treatment of choice and appropriate treatment stage should be initiated post-haste.

Our subjects' CV scores also showed significant positive correlation with central BP or CASP. Our finding suggests a possible revision to the existing $\mathrm{CV}$ risk assessment for young adults and the need to separate this group from the general adult population. Inclusion of additional risk factors and more organ-specific assessments such as abdominal obesity, microalbuminuria, C-reactive protein and homocysteine levels are probably required. If young adults with higher calculated CV risk could be identified earlier and given the appropriate treatment, a reduction in end organ damage would mean a reduction in the total cost of treating these individuals and lower long term morbidity and mortality rates.

\section{Limitations to this Study}

There are two major limitations associated with this study. Firstly, this cross-sectional and observational study behoves that its findings be interpreted with caution. Secondly, the small sample size, low prevalence and single-centre recruitment negates population level extrapolation of the data. Nevertheless, the results and statistical significance achieved underpins the strength of the association despite the small numbers garnered by this study.

Future studies should involve a cohort study of the subjects from this study and assess the progression of the BP vis-à-vis the metabolic abnormalities 
whilst ascertaining if the Framingham risk assessment accurately predicts, overestimates or underestimates the CV risk of the young hypertensive in our sampled population.

\section{CONCLUSIONS}

Greater BMI, FBG, HDL, TG levels and TC/HDL ratio significantly characterised the young adults with early/mild hypertension. Hypertension, in this group is also an accumulation of several clinical abnormalities befitting metabolic syndrome. These findings mirror current literature on the preponderance of metabolic abnormalities among adult patients with essential hypertension. We have also shown that the metabolic anomaly is present at the very early stages of hypertension development thereby suggesting a rehashing of present indications for treatment currently propagated.

\section{ACKNOWLEDGEMENT}

Funding for this research project was provided by the Ministry of Higher Education, Malaysia under the Fundamental Research Grant Scheme (FRGS 0207-66).

\section{REFERENCES}

1. Chobanian AV, Bakris G, Black H, Cushman W, Green LA, Izzo JL, et al. Seventh Report of the Joint National Committee on Prevention, Detection, Evaluation, and Treatment of High Blood Pressure. The National High Blood Pressure Education Program Coordinating, Committee. Hypertension. 2003; 42(6):120652.

2. Levenson JW, Skerrett PJ, Gaziano JM. Reducing the global burden of cardiovascular disease: the role of risk factors. Prev Cardiol. 2002; 5(4):188-99.

3. Padwal R, Straus SE, McAlister FA. Evidence based management of hypertension: Cardiovascular risk factors and their effects on the decision to treat hypertension: evidence based review. BMJ. 2001; 322 (7292):977-80.

4. Kearney PM, Whelton M, Reynolds K, Muntner P, Whelton PK, He J. Global burden of hypertension: analysis of worldwide data. Lancet. 2005; 365(9455):217-23.

5. Lim TO, Zaki M, Hypertension Study Group. Prevalence, Awareness, Treatment and Control of Hypertension in the Malaysian Adult Population: Results from the National Health and Morbidity Survey 1996. Singapore Med J. 2004; 45(1):20-7.

6. Martínez-Vizcaino V, Ortega FB, SoleraMartínez M, Ruiz JR, Labayen I, Eensoo D, et al. Stability of the factorial structure of metabolic syndrome from childhood to adolescence: a 6-year follow-up study. Cardiovasc Diabetol. 2011; 21(10):81.
7. Falkner B. Hypertension in children and adolescents: epidemiology and natural history. Pediatr Nephrol. 2010; 25(7):1219-24.

8. Reaven GM, Lithell H, Landsberg L. Hypertension and Associated Metabolic Abnormalities - The Role of Insulin Resistance and the Sympathoadrenal System. N Engl J Med. 1996; 334:374-82.

9. Hypertension Guideline Working Group. Malaysia Clinical Practice Guideline On Hypertension ( $4^{\text {th }}$ edn). 2013, from http:/ / www.acadmed.org.my/ index.cfm?\&menuid=67

10. McNeill AM, Rosamond WD, Girman CJ, Golden $\mathrm{SH}$, Schmidt MI, East HE, et al. The metabolic syndrome and 11-year risk of incident cardiovascular disease in the atherosclerosis risk in communities study. Diabetes Care. 2005; 28 (2):385-90.

11. Ford ES, Giles WH, Dietz WH. Prevalence of the metabolic syndrome among US adults: findings from the third National Health and Nutrition Examination Survey. JAMA. 2002; 287(3):356-9.

12. Hong $Y$, Jin $X$, Mo J, Lin HM, Duan $Y, P u M$, et al. Metabolic syndrome, its preeminent clusters, incident coronary heart disease and all-cause mortality-results of prospective analysis for the Atherosclerosis Risk in Communities study. J Intern Med. 2007; 262(1):113-22.

13. Razzouk L, Muntner P. Ethnic, gender, and agerelated differences in patients with the metabolic syndrome. Curr Hypertens Rep. 2009; 11(2):127-32.

14. Dekker JM, Girman C, Rhodes T, Nijpels G, Stehouwer CDA, Bouter LM, et al. Metabolic Syndrome and 10-Year Cardiovascular Disease Risk in the Hoorn Study. Circulation. 2005; 112 (5):666-73.

15. Malik S, Wong ND, Franklin SS, Kamath TV, L'Italien GJ, Pio JR, et al. Impact of the Metabolic Syndrome on Mortality From Coronary Heart Disease, Cardiovascular Disease, and All Causes in United States Adults. Circulation. 2004; 110(10):1245-50.

16. Williams B, Poulter N, Brown M, Davis M, McInnes G, Potter J, et al. Guidelines for management of hypertension: report of the fourth working party of the British Hypertension Society, 2004-BHS IV. J Hum Hypertens. 2004; 18(1):139-85. 
